\title{
Can Health Care LaW and Policy Be Guided by Basic VALUES?: THE CRUCIAL ROLE OF PERFECTIONIST SOLIDARITY
}

\author{
R. George Wright*
}

\section{INTRODUCTION}

Debate over American health care law and policy occupies much of our public agenda. In its most responsible forms, this debate acknowledges important value conflicts that cannot be casually dismissed. ${ }^{1}$ The importance of these value conflicts should move us to think not only of moderate policy changes, ${ }^{2}$ but of the role of basic values and principles ${ }^{3}$ in formulating and justifying health care policy. This Article considers some of the most plausible of such basic values, ${ }^{4}$ with an eventual turn toward what we refer to as perfectionist solidarity. ${ }^{5}$ This focus on perfectionist solidarity is intended to encourage greater coherence in our unavoidably complex ${ }^{6}$ debates over

* Lawrence A. Jegen Professor of Law, Indiana University Robert H. McKinney School of Law.

1. Thus we might wish, for example, to allocate health care in response to medical need. See Bernard A.O. Williams, The Idea of Equality, in JusTICE AND EQUALITY 116, 126 (Hugo A. Bedau ed., 1971); Michael Walzer, SPHERES OF JUSTICE: A DEFENSE OF PLURALISM AND EQUALITY 88 (1983). On any reasonable understanding of "need," however, the scope of medical need must then confront the problem of scarcity of resources. See David Braybrooke, MEETING NEEDS 295 (1987).

2. For a classic presentation, see Charles E. Lindblom, The Science of Muddling Through, 19 PuB. ADMIN. REV. 79 (1959). More elaborately, see DAVID BRAYBROOKE \& CHARLES E. LINDBLOM, A Strategy of Decision: Policy Evaluation as a Social Process 81-99 (1965). For a recent assessment, see Jonathan Bendor, Incrementalism: Dead Yet Flourishing, 75 PUB. ADMIN. REV. 194 (2015).

3. For a broad skepticism as to the role of general moral principles, see JONATHAN DANCY, ETHICS Without PRINCIPLES (2004). But see Sean McKeever \& Michael Ridge, Principled Ethics: Generalism as a Regulative Ideal (2006). For discussion in legal contexts, see R. George Wright, Dreams and Formulas: The Roles of Particularism and Principlism in the Law, 37 Hofstra L. Rev. 195 (2008).

4. See infra Section II.

5. See infra Section III.

6. Inevitably, health care law and policy will be complex along a number of dimensions, even before we undertake the typically daunting tasks of empirical investigation. Consider the observations of the widely-respected economist Amartya Sen:

$[\mathrm{H}]$ ealth equity has many aspects, and is best seen as a multidimensional concept. It includes concerns about achievement of health and the capability to achieve good health care. But it also includes the fairness of processes and thus must attach importance to non-discrimination in the delivery of health care. Furthermore, an adequate engagement with health equity also requires that the considerations of health be integrated with broader issues of social justice and overall equity, paying adequate attention to the versatility of resources and the diverse reach and impact of different social arrangements.

Amartya Sen, Why Health Equity?, 11 HeALTH ECONOMICS 659, 665 (2002). For more detailed discussion, see Emily A. Benfer, Health Justice: A Framework (And Call to Action) For the Elimination of Health Inequity and Social Injustice, 65 AM. U.L. REV. 275 (2015). 
health care law and policy.

Any discussion of basic health law and policy values and principles will unavoidably involve a high level of abstraction. Abstract discussion, however, should ultimately be responsive to real and stable motivations and to concretely lived experience. It is of course impossible to survey herein the full range of the effects of health care law and policy at the level of lived experience. Merely for purposes of introducing broader themes, though, let us immediately consider two ordinary judicial cases implicating matters of basic values and principles.

Consider first the case of Abigail Alliance For Better Access to Developmental Drugs v. Eschenbach ${ }^{7}$ Abigail Alliance was decided at a constitutional level, ${ }^{8}$ but the case is essentially one of appropriate interest balancing in the health care context. The plaintiffs in Abigail Alliance sought, on behalf of terminally ill patients, less restricted access to experimental drugs that had passed certain safety tests, but had not yet been established as safe and effective. ${ }^{9}$ The plaintiffs alleged that the typical length of the full cycle of tests for safety and effectiveness was nearly seven years. ${ }^{10}$ On this basis, the plaintiffs objected to the Food and Drug Administration's (FDA) interest balancing, or riskbenefit calculus, in cases of terminally ill patients with no alternative treatment options. ${ }^{11}$

In response, the FDA noted the inevitable tensions among the relevant interests, ${ }^{12}$ including the conflict between early availability of a sole potentially viable treatment ${ }^{13}$ and the broader need to obtain reliable data on the safety and effectiveness of experimental drugs. ${ }^{14}$ Even in some cases of terminally ill patients, the risk of severe drug toxicity and its effect on the quality of the patient's remaining life was accorded some weight. ${ }^{15}$ The Abigail Alliance court found no constitutionally fundamental right to be at stake, ${ }^{16}$ and upheld the FDA's particular interest balancing process under minimum scrutiny. ${ }^{17}$ The court concluded that "the FDA's policy of limiting access to investigational

\footnotetext{
7. 495 F. 3 d 695 (D.C. Cir. 2007). For discussion, see 121 HARV. L. REV. 1685 (2008).

8. See Abigail Alliance, 495 F.3d at 711-12.

9. See id. at 697 .

10. See id. at 698 . Expedited access for terminally ill patients was, however, available in some cases. See id. at 698-99.

11. See id. at 699 .

12. See id. at 700

13. See id.

14. See id.

15. See id.

16. See id. at 711 .

17. See id. at 713
} 
drugs is rationally related to the legitimate state interest of protecting patients, including the terminally ill, from potentially unsafe drugs with unknown therapeutic effects."18

The FDA policy in this case was sensible on certain reasonable assumptions. Yet we can also imagine a substantial class of terminally ill patients, with minimal life expectancies and no alternative therapeutic options, who are willing to trade some risk of adverse side effects or of reduced quality of life for some chance of an effective treatment. Such choices admittedly might well slow the process of meaningful data collection on the treatment in question.

In these cases, the most defensible approach at the level of fundamentals must recognize the rights and interests at stake; assess their rank, priority, or weight; and then bring them into some sort of accommodation. Any such fundamental approach must address the unavoidable scarcities, conflicts, and tradeoffs by reference to what is thought to be the most important underlying basic values at stake in such cases.

Abigail Alliance implicates at least some of the basic values at stake in a wide range of health law and policy cases, as does, in turn, the unrelated Medicaid assistance case of S.L. v. Division of Medical Assistance and Health Services. ${ }^{19}$ In S.L., the 95 year-old appellant spent several months in a care center before exhausting her financial assets available to pay for such care, ${ }^{20}$ at which point she applied for Medicaid benefits to cover the cost of her continuing care. ${ }^{21}$ The agency, in response, imposed a five month eligibility penalty ${ }^{22}$ in light of S.L.'s gifts to her children, totaling $\$ 40,000$, within the preceding two to three year period. ${ }^{23}$

Under the applicable Medicaid eligibility section, ${ }^{24}$ there is a rebuttable presumption that "any assets disposed of by an institutionalized individual for less than fair market value during a period of sixty months before applying for Medicaid assistance is done to establish Medicaid eligibility." 25 The S.L. court found that this

18. See id. For broad theoretical background, see Eric Posner \& Matthew D. Adler, Re-Thinking

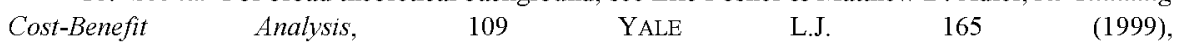
https://chicagounbound.uchicago.edu/cgi/viewcontent.cgi?referer=https://www.google.com/\&httpsredir $=1 \&$ article $=2755 \&$ context $=$ journal_articles.

19. 2014 WL 4289003 (N.J. App. Div. Sept. 2, 2014) (per curiam) (unpublished opinion).

20. See id., slip op. at 1 .

21. See id.

22. See id.

23. See id.

24. 42 U.S.C. $\$ 1396$ p(c)(1)(B)(i).

25. S.L., slip op. at 1. 
presumption, triggering the eligibility delay, was unrebutted. ${ }^{26}$

The court displayed a certain ambivalence in reaching this conclusion. The court noted in particular that Medicaid eligibility in this context is not available to any individual with countable assets or designated kinds of financial resources in excess of $\$ 2,000 .{ }^{27}$ Given the broader context of a large aging baby boomer cohort, ${ }^{28}$ medical advancements, ${ }^{29}$ and technological innovation, ${ }^{30}$ the very meaning of "elderly" was said to be in the process of redefinition. ${ }^{31}$ The court understandably concluded with an appeal for a legislative response: "Our legislature should seriously consider whether it is truly in the best interests of a just society to penalize a parent for trying to give her children a small part of the resources she and her husband accumulated over a lifetime of work." 32

On the one hand, there is a natural sense that a 95 -year old ${ }^{33}$ Medicaid applicant may typically have been much more fortunate, with respect to an ordinary life expectancy, than most of her birth cohort, whatever her current newly developed physical limitations. On the other hand, she may have paid more than her proverbial dues with respect to the financing of the health care system over a productive working life.

Of course, it is also sensible to argue that when more or less "affluent individuals use Medicaid qualifying trusts and similar 'techniques' to quality for the program, they are diverting scarce federal and state resources from low-income elderly and disabled individuals, and poor women and children." 34 It is possible for persons with substantial financial assets to game the Medicaid eligibility system, at the expense of the less well-off. ${ }^{35}$ But it is also possible that such persons face substantial strategic costs in other respects. ${ }^{36}$ Strategic eligibility planning options in this context may even involve a "possible loss of

26. See id., slip op. at 5 .

27. See id. Not surprisingly, given the obvious incentives and the statutory complications, there is an elaborate case law of approved and unapproved ways of evading the relevant asset limits. See, e.g., Daley v. Secretary of HHS, 477 Mass. 188, 74 N.E.3d 1269 (2017) (irrevocable trust instrument).

28. See S.L., slip op. at 5.

29. See id. at 6 .

30. See id.

31. See id. See also Cohen v. Commissioner, Div. of Med. Assistance, 423 Mass. 399, 402, 668 N.E.2d 769 (1996)

32. See S.L., slip op. at 6 .

33. See id. at 1 .

34. Daley, 74 N.E.3d at $1273-84$ (quoting H.R. Rep. No. 265 , 99 th Cong., 1st Sess., pt. 1, at 72 (1985)).

35. See, e.g., the authorities cited supra note 34 .

36. See Daley, 74 N.E.3d at 1276. 
autonomy, pride, and dignity." 37 In particular, Medicaid eligibility rules often encourage the humiliating disruption of the elemental solidarity of married persons and their intact marriage by financially incentivizing an otherwise unappealing legal divorce. ${ }^{38}$

Merely from these two nearly randomly chosen judicial cases, we can develop some initial sense of the most basic underlying values at stake in health care law and policy, as well as possible conflicts and tradeoffs among those values. Implicit within the two selected judicial cases above are considerations of the possible roles in health care law and policy of various ideas of equality; ${ }^{39}$ a fair opportunity to live, with whatever quality of life, for some culturally standard or meaningful time ${ }^{40}$ the fairness of health policies that either act upon or else ignore one's pre-existing health vulnerabilities ${ }^{41}$ and the closely related ambivalent character of the idea of insurance, ${ }^{42}$ the distinctive context of expensive end-of-life cases, ${ }^{43}$ the virtues and vices associated with personal dependence ${ }^{44}$ and with Stoicism and related schools of thought, ${ }^{45}$ and the crucial roles of solidarity and some not particularly controversial forms of perfectionism. ${ }^{46}$ The attempt to recognize and properly accommodate each of these health care values will lead to an ultimate emphasis on what we may call the value of perfectionist solidarity. ${ }^{47}$ We pursue this inventory and assessment below.

\section{The Ultmately Abstract IdEA of Equality in Health Care LAW AND POLICY}

Equality, in the sense of the equal protection of the laws, is enshrined at the federal constitutional level. ${ }^{48}$ As it happens, though, apart from

37. Id. Consider in particular the Medicaid program's perverse incentivizing of legal divorce for eligibility and asset-preservation purposes. For discussion, see, e.g., Rev. Amy Ziettlow, Is Divorce the Best Option For Elderly Americans?, HufFington Post (May 16, 2015), https://Www.huffingtonpost.com/rev-amy-ziettlow/is-divorce-the-best-option-for-olderamericans_b_6878658.html and note 122 infra.

38. See the authorities cited supra note 37.

39. See infra Section II.

40. See the "fair innings" argument infra note 83.

41. See infra notes 84-97 and accompanying text

42. See id.

43. See infra notes 113-122 and accompanying text.

44. See infra note 95 and Section III more generally.

45. See infra notes 123-126 and accompanying text.

46. See infra Section III.

47. See id. and text accompanying notes 127-140 in particular.

48. See U.S. ConST. amend. XIV, art. 1 ("No State shall . . . deny to any person within its jurisdiction the equal protection of the laws."). See also, at the federal level, Bolling v. Sharpe, 347 U.S. 497 (1954). For a recent exceptionally thoughtful attempt to articulate the basis or bases for universal 
some particular contexts, ${ }^{49}$ no federal constitutional right to the provision of even basic health care has been recognized. ${ }^{50}$ So equality, in a constitutional sense, currently does not meaningfully inform, guide, or underlie current health care law and policy.

Constitutional equal protection of the laws, however, does not begin to exhaust the potentially relevant understandings of the idea of equality. Perhaps the most sophisticated and detailed theoretical approach to health law and policy is that developed by Professor Norman Daniels. ${ }^{51}$ Professor Daniels elaborately develops and contextualizes John Rawls's broader understanding of justice as fair equality of opportunity. ${ }^{52}$ Roughly, the idea is that one's health is typically crucial to the range and value of one's exercisable life-opportunities. ${ }^{53}$ On Professor Daniels's theory, the idea of normal functioning ${ }^{54}$ mediates between one's health and having fair equality of opportunity. ${ }^{55}$ Health and health care opportunities are unjust, on Daniels's view, when they result from "an unjust distribution of the socially controllable determinants of population health." 56 Thus health care justice is impossible without attention to justice and equality in the many dimensions of life that affect one's real opportunities. ${ }^{57}$

Crucially, though, Professor Daniels recognizes that "the fair equality of opportunity principle is too general and indeterminate" 58 to address a

equality of persons, see JEREMY WALDRON, ONE ANOTHER's EQUALS: THE BASIS OF HUMAN EQUALITY (2017).

49. See the special custodial relationship obligation discussed in, e.g., Wideman v. Shallowford Cmty. Hosp., Inc., 826 F.2d 1030, 1034 (11th Cir. 1987).

50. See id; Harris v. McRae, 448 U.S. 297, 317-18 (1980); Wideman, 826 F.2d at 1034. See also Elizabeth Weeks Leonard, State Constitutionalism and the Right to Health Care, 12 U. PA. J. ConsT. L. 1325,1328 (2010) (noting the view that the federal Constitution is largely a charter of negative, as opposed to positive, rights. As a matter of the collective good, though not of individual health care right, universal vaccination may be required. See Jacobson v. Massachusetts, 197 U.S. 11 (1905).

51. See in particular Norman Daniels, Just Health: MEETING HEALth NEEds Fairly (2008). For a more condensed treatment, see Norman Daniels, Justice and Access to Health Care, STANFORD ENCYCLOPEDIA OF PHILOSOPHY (rev. ed., Febnary 11, 2013), http://plato.stanford.edu/entries/justice-healthcareaccess/.

52. See, e.g., John RAWLS, A THEORY OF JUSTICE $§ 14$, at $73-78$ (rev. ed. 1999).

53. See, e.g., DANIELs, JUST HEALTH, supra note 51 , at 140.

54. See id.

55. See id.

56. Id. We would then need a theory of what sorts of conditions are "socially controllable." That theory would have to itself incorporate theories of justice in health-related policy, as well as highly speculative projections as to the extent to which conditions could be remedied or prevented by various kinds of expensive, currently infeasible, or highly invasive or otherwise objectionable procedures. Feasibility also depends crucially upon adopting some chosen time frame. Many health-related conditions are socially controllable, even over the long term, only by objectionable or apparently disproportionately costly measures.

57. See Daniels, JuST HeAlth, supra note 51, at 140.

58. Daniels, Justice and Access to Health Care, supra note 51, at 13. 
number of equality- and efficiency-related choices and tradeoffs. We might generally wish, for example, to prioritize addressing the needs of persons who are well below average in terms of health. Such an approach might well promote equality in some sense. But we would also have to think about whether to follow such a policy if the real health benefits ${ }^{59}$ to the worse off in some given case were unfortunately fleeting or quite limited by comparison with those that could be gained by reallocating the resources in question to persons only somewhat better off-and still perhaps below average in health-who would more substantially benefit over a longer time from those reallocated resources. ${ }^{60}$ In many contexts, after all, being worse off in terms of health may tragically involve only minimal, temporary, or no meaningful responsiveness to any particular therapy.

Health and health care inequalities as well do not typically manifest themselves in tidy binaries. For some given therapy, the worst off potential patients may be unresponsive; the slightly better off potential patients may be, on the average, somewhat more responsive; and those substantially better off-perhaps still below the health median-may often be actually cured. Professor Daniels recognizes that we lack a consensus as to how to address such problems, whether we add in any realistic further complications and uncertainties or not. ${ }^{61}$ Given these and other challenges to his theory of fair equality of health opportunity and to any related theories, Professor Daniels seeks a procedural, rather than a substantive, resolution. ${ }^{62}$ Lacking a consensus on the moral ranking of any particular form of equality, "we should engage a form of procedural justice or fair process to yield fair outcomes." 33

But the problem with seeking to bypass any substantively-based choosing among conflicting health care policies by appealing instead to the results of fair decision-making procedures, or to a fair decision-

59. The term "benefit" here does not require any actual positive improvement in one's health, as distinct from either avoiding, postponing, or slowing the rate of deterioration of some medical condition. For background in the Medicare funding context, see, e.g., Federal Court Approves CMS Corrective Statement to Enforce Jimmo Settlement, Center For Medicare Advocacy (February 16, 2017), http://www.medicareadvocacy org/federal-court-approves-cms-corrective-statement-to-enforce-jimmosettlement/.

60. See Daniels, Justice and Access to Health Care, supra note 51, at 13 .

61. See id.

62. See id.

63. Id. As merely one possible procedural model, consider the Oregon health care funding priorities and funding cut-offs referred to in, e.g., Philip A. Perry \& Timothy Hotze, Oregon's Experiments with Prioritizing Public Health Care Services, 13 AM. J. OF ETHICS, 241-247 (2011). http://journalofethics.ama-assn.org/2011/04/pforl-1104.html. For the current Oregon processes of stakeholder and other public input and participation, see State Health Improvement Plan, OREGON.GOV, www.oregon.gov/oha/PH/About/Pages/HealthImprovement.aspx (last visited July 21, 2017) (listing seven revisable general substantive health priorities) (current priorities as including tobacco use, obesity, oral health, alcohol and substance abuse, suicides, immunization, and communicable diseases). 
making process, is clear. The fairness of any particular decision-making procedure, including voting processes, is plainly no less contestable than are substantive political and legal questions. What is the procedurally fairest way to elect state and federal officials? Are voting apportionment and reapportionment principles morally or politically uncontroversial? Worse, many of the elements of our substantive policy disputes have analogues, if not mirror images, in the realm of voting and more general procedural fairness. A procedural focus such as that of Professor Daniels thus largely re-inscribes the substantive policy debates we had thereby hoped to bypass.

Nor, in the alternative, can we arrive at any reasonably determinate guiding substantive principle by taking the edge off strict versions of egalitarianism. The approach to distribution of goods and services known as prioritarianism, for example, gives some merely unspecified additional moral weight to the interests of persons who are deemed illcircumstanced $^{64}$ in some supposedly absolute, and supposedly noncomparative or non-relative, sense. ${ }^{65}$ The prioritarian thus might be willing to fund important surgeries for a limited number of the worst off patients, even at the expense of not funding a greater number of less serious surgeries for a greater number of somehow absolutely better off persons. Thus the prioritarian is not always disposed to maximize utility, or overall collective health-related well-being. ${ }^{66}$

But it is also true that a prioritarian might object to funding a limited number of only minimally or modestly beneficial surgeries for the desperate, at the expense of more genuinely beneficial surgeries for a number of patients in non-desperate circumstances. ${ }^{67}$ The point here is

64. See, e.g., Greg Bognar \& IWao Hirose, The Ethics of Health Care Rationing 1 19-22 (2014); Derek Parfit, Equality and Priority, 10 RATIO 202, 213 (1997); Michael Weber, Prioritarianism, 9 PHIL. COMPASS 756 (2014).

65. See Parfit, Equality and Priority, supra note 64, at 214. The point of trying to assess the weight of interests in some non-comparative way is to try to more clearly distinguish prioritarianism from stricter, more rigorous versions of egalitarianism. Whether we can really distinguish absolute and relative or comparative aspects of a typical person's overall health circumstances need not be pursued here. For discussion of some aspects of a number of approaches to egalitarianism, see R. George Wright, Equal Protection and the Idea of Equality, 34 L. \& INEQUALITY 1 (2016).

66. See Parfit, Equality and Priority, supra note 64, at 213.

67. See id.; Daniels, Justice and Access to Health Care, supra note 51, at 13. In more extreme terms, prioritarian theories seek to avoid what is called the "leveling down" problem of more strict forms of egalitarianism. The leveling down problem might involve, for example, a society that can reduce inequality of vision health not by improving the vision of those with deficient vision, but only by impairing the vision of those who see clearly. For discussion, see e.g., BRAD HOOKER, IDEAL CODE, REAL WORLD 43 (2000). For some real world quandaries for the prioritarian, see Jerome Bickenbach, Disability and Health Care Rationing, STANFORD ENCYCLOPEDIA OF PHILOSOPHY (January 29, 2016), http://plato.stanford.edu/entries/disability-care-rationing at 15 . For law-related background, see R. George Wright, Persons With Disabilities and the Meaning of Constitutional Equal Protection, 60 OHIO ST. L.J. 145 (1999). 
again not to critique any form of prioritarianism, but mainly to suggest the practical indeterminacy of prioritarian approaches to health care law and policy.

A further generally, but not strictly, egalitarian approach to health care law and policy encompasses a number of variants under the heading of sufficientarianism. ${ }^{68}$ Sufficientarian approaches to health care are built on the belief that neither equality nor a reasonably close approach to equality in health care need be sought. What is thought to be crucial, instead, is that persons receive what is somehow thought to be enough health care, or decent health care, or sufficient health care. ${ }^{69}$

Sufficientarianism, like prioritarianism, ${ }^{70}$ seeks to distinguish supposedly "absolute" elements of health and health care from comparative or relative considerations. ${ }^{71}$ We can certainly see the appeal of a system in which everyone receives at least some baseline level of health care, at least as opposed to a system in which everyone receives equal health care, but only at a level well below any meaningful baseline. $^{72}$

But again, unavoidable indeterminacies and complications aside, health care sufficientarianism would, with certainty, prefer to move a very limited number of persons from the category of just barely below sufficient care into the lowest ranks of sufficiency of care where no one would, we assume, thereby be moved from sufficiency to insufficiency. The problem, though, is that pure sufficientarianism would also insist on this minimal upgrade into bare sufficiency even where a large number of persons already below the sufficiency baseline would as a consequence suffer a significant decline in their health care, such that they would then be notably even further away from the baseline level of sufficiency. ${ }^{73}$

68. For some general underlying theory, see GEORGE SHER, EQUALITY FOR INEGALITARIANS vii (2014); Harry Frankfurt, The Moral Irrelevance of Equality, 14 PUB. AFF. Q. 87, 91 (2000); Harry Frankfurt, Equality as a Moral Ideal, 98 ETHICs 21, 21 (1987). At book length, see Harry Frankfurt, ON INEQUALITY (2015). See also Kees Schuyt, The Sharing of Risks and the Risks of Sharing: Solidarity and Social Justice in the Welfare State, 1 ETHICAL THEORY \& MORAL PRAC. 297, 298 (1998).

69. See the sources cited supra note 68. It is possible that Professor Paul Starr's approach might count as an example of a form of sufficientarianism. See PAUL STARR, REMEDY AND REACTION: THE Pectliar American Struggle Over Health Care Reform 242 (rev. ed. 2013) (referring to cosmetic surgery, private hospital room access, and moral hazard problems as possible limits on equality of provision)

70. See supra note 65 and accompanying text.

71. See Sher, supra note 68, at viii; Frankfurt, The Moral Irrelevance of Equality, supra note 68, at 91. Again, a distinction between absolute and relative well-being is often contestable.

72. This point reinforces not only the 'leveling down' problem of many forms of egalitarianism, see supra note 67 , but also suggests the values of technological and genuine economic growth, meaningful progress, and some forms of perfectionism. See infra Section III.

73. For background, see Paula Casal, Why Sufficiency Is Not Enough, 117 ETHICS 296, 298 (2007); Liam Shields, The Prospects of Sufficientarianism, 24 UTILITAS 101, 101 (2012). Of course, we can imagine variations of pure sufficientarianism, or combinations of sufficientarianism with other 
No focus on moving persons from bare insufficiency to bare sufficiency can afford to ignore substantial costs to other persons below the sufficiency level who may be made worse off by some particular policy.

The point of raising such unattractive possibilities is again not to establish that sufficientarianism, like prioritarianism and strict egalitarianism, definitely gives us wrong answers in some cases. The point is rather that even before we consider questions of motivation, sufficientarianism's indeterminacies can be resolved only arbitrarily, or through some contestable intuition, or by some other specification with no obvious capacity for generating a distinctive consensus in its favor. There are no obvious lines, descriptive or normative, among minimal care; care that is barely below sufficiency; bare sufficiency; necessary care; decency of care; ${ }^{74}$ and care that is appropriate for various levels of an advanced, reasonably high-productivity economy. ${ }^{75}$

Given the indeterminacies of these varieties of egalitarianism, it is tempting to try to bypass some of the complications by adopting some version of what is referred to as "luck egalitarianism." idea of luck egalitarianism is that there are some conditions and outcomes for which it is reasonable to hold the "actor" in question fully or partially responsible. ${ }^{77}$ And in contrast, there are also thought to be other conditions and outcomes for which it would not be reasonable to hold the "actor" responsible. ${ }^{78}$ Thus being born with an exceptionally

approaches to equality or other values that would accommodate this particular concern. Even if some such subtle hybrid could be popularized, however, the basic problem of its abstractness, and its limited motivational power by comparison with the bonds of genuine solidarity, would remain. Persons can be precisely equal in some relevant respect, yet mutually utterly indifferent. See infra Section III.

74. See Stephen Nathanson, Equality, Sufficiency, Decency: Three Criteria of Economic Justice, 30 PHIL. RESEARCH 367 (2005). The practicality of attempts to distinguish between health care access that is described as basic, decent, or equitable and some more expansive provision of health care is questioned in TOM L. BEAUCHAMP \& JAMES F. CHILDRESS, PRINCIPLES OF BIOMEDICAL ETHICS 271-74 (7th ed., 2013). The logic of continuous expansionism in health care reflects not just economic growth, technological change, economics of scale, and age demographics, but the interest group public choice dynamic explored in MANCUR OLSEN, THE LOGIC OF COLLECTIVE ACTION: PUBLIC GOODS AND THE THEORY OF CHOICE (1965).

75. For discussion of some indeterminacies of the idea of a minimum of health care, along with adequacy in health care, necessary health care, and equality, see Einer Elhauge, Allocating Health Care Morally, 82 CAL. L. REV. 1451 (1994).

76. For background, see RONALd DWORKIn, SOVEREIGN VIRTUE: THE THEORY AND PRACTICE OF EQUALITY 73-83 (2000); KASPER LIPPERT-RASMUSSEN, LUCK EGALITARIANISM (2016); SHLOMI Segald, Health, LuCK, AND Justice (2010). See also Shlomi Segall, Is Health (Really) Special?: Health Policy Between Rawlsian and Luck Egalitarian Justice, 27 J. APPLIED PHIL. 344 (2010); Shlomi Segall, In Solidarity With the Imprudent: A Defense of Luck Egalitarianism, 33 SOCIAL THEORY \& PRAC. 177 (2007).

77. See, e.g., Kok-Chor Tan, A Defense of Luck Egalitarianism, 105 J. PHIL. 665, 665 (2008); Iwao Hirose, EGALITARIANISM ch. 7, at 157 (2015) (distinguishing health care system responses to the heart disease of smokers and of non-smokers).

78. See IWAO HIROSE, EGALITARIANISM (2015). This distinction is vaguely related to the broad insurance concept of "moral hazard." See, for background, Tom Baker, On the Genealogy of Moral 
expensive medical condition is not said to be the responsibility of that person. Such a condition was never in any sense chosen by, attributable to, caused by, or the fault of that person. In that sense, the adverse health condition is morally arbitrary, as opposed to being somehow deserved.

On the other hand, someone who had entirely run a particular risk freely and knowingly in hope of obtaining some benefit is typically thought, despite the role of luck involved, ${ }^{79}$ to be relevantly responsible for the undesired outcome of that free choice. Given these assumptions, luck egalitarianism tends to hold the first person, with the unchosen illness, to be a better candidate for publicly funded medical assistance or other compensation than the second, assumedly freely risk-running person. ${ }^{80}$

Hazard, 75 TEX. L. REV. 237, 237 (1996) ("[t]o what extent are those who suffer responsible for their condition?"). But more precisely, "moral hazard' refers to the tendency for insurance against loss to reduce incentives to prevent or minimize the cost of the loss." Id. at 239. Classically, see Kenneth J. Arrow, Uncertainty and the Welfare Economics of Medical Care, 53 AM. ECON. REV. 941 (1963). More broadly, "it seems not psychologically extraordinary for people's sense of obligation toward others to be reduced when they can count on institutions to take care of these obligations." LippertRasmussen, supra note 76, at 224.

79. For this basic distinction between "brute luck" and "option luck," see Dworkin, supra note 76 , at $73-83$.

80. It is possible for a luck egalitarian to avoid apparently harsh practical implications in the case of a person who knowingly and freely ran either a low or a high probability risk, perhaps as in skiing or mountain climbing, and is now in need of expensive long-term medical care. A luck egalitarian could concede that justice itself does not require public payment of such expenses, but that other values and virtues, perhaps including compassion, empathy, or, as we emphasize, solidarity, may operate to mitigate the harshness of an undiluted luck egalitarianism. For discussion, see Segall, Is Health (Really) Special?, supra note 76 , at $\S 4$. Otherwise, "it might be that tragically, there is a trade-off between implementing luck egalitarian justice and promoting communal motivations." Lippert-Rasmussen, supra note 76 , at $225-26$.

The emphasis in luck egalitarianism on genuine freedom of choice may suggest that the crucial guiding principle for a health care system should actually be individual freedom. There is a substantial contemporary literature analyzing and critiquing the idea of individual freedom. See, e.g., Christian Bay, THE Structure of FreEdom (rev. ed. 1970); IsAiaH Berlin, Liberty: INCORPORATING FOUR ESSAYS ON LIBERTY 166 (Henry Hardy 2d ed., 2002) (classically seeking to distinguish "negative" from "positive" freedom); IAN CARTER, A MEASURE OF FREEDOM (2004); Richard E. Flathman, The Philosophy and Politics of Freedom (1987); Charles Fried, MODERN LIBERTY AND THE LIMITS OF GOVERNMENT (2007); MATTHEW H. KRAMER, THE QUALITY OF FREEDOM (2008); KRISTJAN KRISTJANSSON, SOCIAL FREEDOM: THE RESPONSIBILITY VIEW (2007); FELiX OPPEHEIM, Dimensions of FrEedom: An ANAlysis (1961); Christine SWANTON, FreEdom: A COHERENCE THEORY (1992); GLENN TINDER, LIBERTY: RETHINKING AN IMPERILED IDEAL (2007).

The literature ultimately implies, however that individual freedom is unsuitable as a fundamental guiding principle for health law and policy. Individual freedom instead has its place as a typically secondary consideration in health care policy. Freedom as the absence of social restraint on choice might be maximized in having available a variety of voluntary health insurance and health care markets. Such markets would presumably be diversely supplemented by voluntary gifts and other forms of charity, individual or group-based.

The default practice, though, on which free buyers and free sellers are likely to agree, would likely involve the segmentation of relatively low cost policies for those whose profiles predict good health, and either high cost or no meaningful insurance policies for persons likely, through no fault of 
In this context, the deepest and most important source of indeterminacy for our purposes is the absence of anything like a consensus on the meaning, status, value, and role of responsibility in the relevant sense. ${ }^{81}$ But even if we set aside the most fundamental disputes, the indeterminacies of luck egalitarian approaches are still pervasive. Consider, for example, the context of diseases related to tobacco use. Genetic predispositions aside, should we say that the typical long-term smoker has more or less freely and knowingly incurred at least some substantial responsibility for a commonly resulting disease? Would such an assessment have been the same a hundred years previously?

Could we not crucially complicate matters by then considering issues of addictiveness, along with the largely unchosen environmental effects of basic socio-economic class status? Some persons may have only

their own, to require continuing or other high-cost care. Broad health insurance risk-pooling, even where it occurs on this understanding of individual freedom, would typically reflect something like voluntary charity, ignorance, or high costs of predicting future health status. This simple model of individual transactional freedom would then be complicated by variations in the degrees to which persons plan for or discount their own future needs.

Individual freedom with respect to health care law and policy would thus seem, for example, to largely consign persons with expensive birth defects and those in obvious need of long-term care to prohibitively expensive or limited policies or to the contingencies of private individual or group charity. Any persons who are unable to attract such voluntary charity would presumably be out of luck. And such charity notoriously suffers from problems of coordination, collective action, and free-riding. See ALLEN BUCHANAN, ETHICS, EFFICIENCY, AND THE MARKET 71-74 (1988).

There will, however, be some health care contexts in which individual freedom may assume a more important role, as in many cases inviting the availability of euthanasia or assisted suicide. See, e.g., Gerald Dworkin, R.G. Frey, and Sissela BoK, EutHanasia and Assisted Suicide (1998); Washington v. Glucksberg, 521 U.S. 702 (1997).

It is, however, also possible to re-conceive of the idea of individual freedom in a more "positive" sense. In this positive sense, freedom is largely a matter not of subjective personal choice among options, but of genuine development, self-realization, flourishing, or fulfilling one's potential. See Berlin, supra, at 166 .

It is clearer in this positive sense that, for example, persons with serious but potentially remediable mobility limitations are typically, but not invariably, less than fully free. Lack of opportunity to develop mobility potential must, certainly, be somehow weighed against the costs, in terms of their own self-realization, of other persons who might be legally required to pay for treatment and accommodations for persons in this limited mobility category.

More crucially, though, freedom in a "positive" or developmental sense can be largely reduced to the value of flourishing or self-realization itself, without any further reference to any conception of freedom. Individual and collective self-realization or flourishing can be explored and valued on their own terms. The idea of freedom really adds nothing further of substance. And as it turns out, individual and collective self-realization or development over time is central to our discussion below perfectionist solidarity as a basic value or guiding principle for health care law and policy. See infra Section III.

81. For a sense of the range of approaches to the idea of responsibility, or the lack thereof, for one's behaviors, see JOHN MARTIN FISHER \& MARK RAVIZZA, RESPONSIBILITY AND CONTROL: A THEORY OF MORAL RESPONSIBILITY (1998); DERK PEREBOOM, LIVING WITHOUT FREE WILL (2001); Saul SMilansky, Free Will and Illusion (2000); Matthew Talbert, Moral Responsibility: AN INTRODUCTION (2016); BRUCE N. WALLER, AGAINST MORAL RESPONSIBILITY (2011). 
modestly greater realistic choice with regard to their basic economic or class environment than with their genetic makeup, or any interaction between their genes and environment. Could not members of distinctly different classes often have different degrees of relevant knowledge and freedom of choice with respect to smoking or continuing to smoke, and thus different degrees of responsibility? But if so, how are any such differences to be measured, and then, even more controversially, differentially addressed by the health care system?

One might seek recourse here to the idea of personal "effort." The idea would be that effort, in the sense of repeatedly attempting to quit smoking at some meaningful time, should to some degree diminish one's personal responsibility for reasonably foreseeable medical consequences. On the other hand, exerting modest or no effort to quit smoking might tend to enhance or confirm one's responsibility for such medical consequences. But the idea of a capacity to make an 'effort' is itself mired in the indeterminacies of responsibility and is therefore of little use in establishing the practicality of luck egalitarianism. ${ }^{82}$

Ultimately, though, the crucial problem is that inequality, in itself, is typically not emotionally experienced with any sustained fervency and thus does not typically meaningfully motivate potentially self-sacrificial action. In none of its conflicting forms does the idea of equality sufficiently motivate sustained practical commitment to any reasonably determinate value or principle capable of meaningfully guiding fundamental health care law and policy. ${ }^{83}$ Let us therefore turn to the

82. Compare, e.g., Nicholas Barry, Reassessing Luck Egalitarianism, 70 J. POLITICs 136, 140 (2008) (personal effort or ambition as actually largely attributable to external influences) with THOMAs NAGEL, EQUALITY AND PARTIALITY 118 (1991) (with some exceptions, "the level of someone's effort is the result of free choice").

83. Another variant on the idea of equality is that of the so-called "fair innings" argument. For background, see, e.g., Alan Williams, Intergenerational Equity: The 'Fair Innings' Argument, 6 HEALTH ECONOMICS 117 (1997). On Williams' view, everyone is more or less entitled to some qualityadjusted normal span of years-perhaps the proverbial three score and ten. Thus surviving from age 80 to 85 is of less moral significance than surviving as a child, or than surviving from age 20 to 25 . The egalitarian implication is that medical resources should, all else equal, be shifted from the elderly toward the relatively young, presumably with serious ailments. The idea is roughly that the death from illness of a young person is a tragedy, or a loss of potential, in a way that the death of an elderly person, all else equal, cannot match. On its own terms, the "fair innings" approach typically does not account for degrees of chronic or long-term pain and suffering; or for differences in amenability to meaningful treatment; or for any differences in health life-styles and behavioral risk factors, including smoking, drinking, and obesity. See, e.g., Neil Mehta \& Mikko Myrskyla, The Population Health Benefits of a Healthy Lifestyle: Life Expectancy Increased and Onset of Disability Delayed, HEALTHAFFAIRS.ORG (Aug. 2017), http://content.healthaffairs.org/content/early/2017/07/17hlthaff.. For commentary and critique, see, e.g., Bognar \& Hirose, supra note 64, at 91-94; Erik Nord, Concerns For the Worse Off: Fair Innings Versus Severity, 60 SOCIAL SCIENCES \& MEDICINE 257 (2005), www.sciencedirect.com/science/article/pii; Michael M. Rivlin, Why the Fair Innings Argument Is Not Persuasive, BMC MEDICAL ETHICS (December 21, 2000), http://bmomedethics.biomedcentral.com/articles/10.1186/1472-6939-1-1; Amartya Sen, Why Health 
alternative approach of emphasizing the typically more intrinsically or fully emotionally infused, and thus potentially motivating, value of solidarity as a fundamental guide to issues of health care law and policy.

\section{The IdEA OF SOLIDARITY AS A BROADLY APPLICABLE AND Substantially Motivating Value of Health Care LaW ANd Policy}

One approach to understanding the potential guiding role of solidarity in health care law and policy is to begin with the idea of solidarity in only a minimal sense. Specifically, consider the idea of actuarial fairness in insurance, and of narrowness and breadth in insurance risk pooling. The basic question in this regard is whether, or in which cases, it is legitimate to distribute the risks of illness by compelling persons to somehow share such risks, even when some persons would prefer some other approach. ${ }^{84}$ Out of sheer self-interest, persons who think of themselves as healthy, now and for some relevant time in the future, might well prefer an actuarialist approach in which their presumably minimal health risks are shared only with a pool of very similarly situated healthy persons, resulting in, for them, relatively low insurance premiums. ${ }^{85}$ Whether they could self-interestedly prefer this narrow pooling over a full lifetime, including old age, is of course subject to greater doubt.

Thus while health insurance and other forms of insurance require some degree of risk pooling or risk mutualization, ${ }^{86}$ the degree of pooling or mutualization may vary from quite minimal to quite expansive and broadly inclusive. In terms of the idea of solidarity, we might formulate the two main alternatives as, first, a more or less narrowly limited "chance" solidarity, ${ }^{87}$ and more expansive and inclusive "subsidizing" solidarity. ${ }^{88}$

Equity?, 11 HEALTH ECONOMICS 659 (2002) (noting typically observed differences in overall life expectancies as between men and women).

84. See Kenneth S. Abraham, Distributing Risk: InsuranCE, Legal Theory, AND PubliC POLICY 3 (1986).

85. See Xavier Landes, How Fair Is Actuarial Fairness?, 128 J. Bus. ETHICs 519, 519 (2015); Jan Abel Olsen, Concepts of Equity and Faimess in Health Care, in OXFORD HANDBOOK OF HEALTH ECONOMICS ch. 34, at 820 (Sherry Glied \& Peter C. Smith eds., 2013).

86. See Christian Thimann, What Is Insurance and How Does It Differ From General Finance?, THE ECONOMICS, REgULATION, AND SYSTEMIC RISK OF INSURANCE MARKETS 5, 6 (Felix Hufeld et al., eds., 2017).

87. See Turo-Kimmo Lehtonen \& Jyri Liukko, The Forms and Limits of Insurance Liability, 103 J. Bus. Ethics 33, 33 (2011).

88. See id. See also Michael J. SAndel, The CASE Against Perfection 89-90 (2007) (usefully distinguishing forms of insurance that merely "mimic" real solidarity and those forms embodying and expressing more intensive solidarity); DEBORAH STONE, BEYOND MORAL HAZARD: INSURANCE AND MORAL OPPORTUNITY, IN EMBRACING RISK: THE CHANGING CULTURE OF INSURANCE AND RESPONSIBILITY ch. 3, at 53 (Tom Baker \& Jonathan Simon eds., 2002). 
A relatively pure actuarial approach to health insurance thus involves solidarity, if at all, in only the most attenuated sense. ${ }^{89}$ Limited, or nonsubsidizing, insurance solidarity requires no renunciation of personal selfishness, egoism, or self-seeking. ${ }^{90}$ Limited insurance "solidarity" thus correspondingly requires no empathy, bonding, meaningful group identity, or even shared values. ${ }^{91}$

One might well conclude that this sort of minimal, non-subsidizing solidarity is thus no solidarity at all, in the normal sense of the word. Contemporary health insurance models in the United States vary in their degree of embodied solidarity. In general, mainstream Republican approaches tend to allow for the narrowing or homogenization of risk pools, ${ }^{92}$ such that currently healthy persons can self-segregate into less costly, perhaps high-deductible policies with limited benefits. ${ }^{93}$ Mainstream Democratic approaches, whether single-payer or otherwise, tend to promote more inclusive, broadly subsidizing risk pools, ${ }^{94}$ where the premiums for currently ${ }^{95}$ healthy individuals offset the greater current and even future health care costs of chronically ill, high risk, or severely ill persons. ${ }^{96}$ The latter approaches thus tend to more fully accommodate, embody, or facilitate mainstream elements of a genuine solidarity. ${ }^{97}$

Solidarity in practice thus involves a transcendence of mere

89. See Lehtonen \& Liukko, supra note 87 , at 36

90. See id.

91. See id. See also Hans-Georg Gadamer, Friendship and Solidarity, 39 RES. IN PHENOMENOLOGY 3, 11 (200) ("[a]uthentic solidarity must be conscious"). This usage reflects the fact that the word "solidarity" is used in a variety of senses, often thinner and less demanding than the senses to which we refer herein. See Segal, In Solidarity With the Imprident, supra note 76, at 195 ("[a]dmittedly, solidarity is a multiply-ambiguous term").

92. See Drew Altman, High-Risk Pools as Fallback for High-Cost Patients Require New Rules, THE HENRY J. KAISER FOUNDATION (January 23, 2017), www.kff.org/health-reform/perspective/highrisk-pools-as-fallback-for-high-cost-patients at 1

93. See id. See also Linda Blumberg \& John Holahan, Don't Let the Talking Points Fool You: It's All About the Risk Pool, HEALTH AFFAIRS (March 15, 2016), https:/Www.healthaffairs.org/do/10.1377/hblog20160315.053952/full/.

94. See id:; Tom Baker, Risk Insurance and the Construction of Responsibility, in EMBRACING Risk: The Changing Culture of InSuRANCE AND Responsibility 33, 46 (Tom Baker \& Jonathan Simon eds., 2002).

95. Few persons, of course, will qualify as healthy, self-sufficient, and independent over an entire life-span, which should encourage a reassessment of the merits of non-solidaristic approaches to health insurance. For a sophisticated treatment of initial and eventual health dependence, see ALASDAIR MACINTYRE, DEPENDENT RATIONAL ANIMALS: WHY HUMAN BEINGS NEED THE VIRTUES ch. 1 (2001). See also DAVID WigGINS, ETHICS: TwELVE LECTURES ON THE PHILOSOPHY OF MORALITY 247 (2006).

96. See Altman, supra note 92, at 1.

97. See supra text accompanying notes 90-91. This is not to suggest that solidarity in a full sense is limited to a bond or commitment between social or economic equals. There can be genuine solidarity, for example, in war time between an officer and a private, as there can be between a local philanthropist and her beneficiaries. For background, see Albert Weale, Equality, Social Solidarity, and the Welfare State, 100 ETHICS 473, 477-78 (1990). 
aggregated ${ }^{98}$ individual interests. ${ }^{99}$ Meaningful solidarity "is associated with mutual respect, personal support, and a commitment to a common cause." 100 In particular, there is typically a sense that "[w]e are all in this together, subject to poor health and the threat of death."101 The genuine solidarity theorist infers that " $[\mathrm{w}] \mathrm{e}$ should mutually support each other against these evils and travails, in part because we are part of the same national or ethnic community, but in part because we all share the human condition." 102

Short of completely universal solidarity across time and space, solidarity may take the form of generosity ${ }^{103}$ toward a narrower or a larger class of persons with whom we identify, ${ }^{104}$ without any expectation of reciprocal generosity, ${ }^{105}$ or even gratitude, in return. ${ }^{106}$ Solidarity, in contrast with calculative self-seeking, may thus require some substantial degree of personal sacrifice ${ }^{107}$ at the expense of even one's long-term self-interest. ${ }^{108}$

More positively, real solidarity involves presumably motivational

98. For background, see IWAO HIROSE, MORAL AGGREGATION 1-36 (2015).

99. See ANDREW MASON, COMMUNITY, SOLIDARITY AND BELONGING 21 (2000) ("[w] wen the individual members of a group genuinely act together (as opposed to merely coordinate their actions in response to each other), they have goals and perform actions which are not reducible to the goals and actions of those individuals considered separately, even though the group does not exist independently of its having individual members").

100. Daniel Callahan \& angela Wasunna, Medicine and the Market: Equity V. CHOICE 113 (2006) (citation omitted).

101. Id.

102. Id. at 113. See also Waldron, supra note 48. Note that if actual persons were to agree to be bound by the basic health care law principles that would be adopted by risk-neutral choosers behind a modified Rawlsian veil of ignorance, they might well settle upon a more or less solidaristic set of basic principles. But adopting and choosing to be bound by this process would clearly reflect the acknowledgement, on the part of currently healthy persons, of the strict moral irrelevance of their own arbitrary current health advantages. Their willingness to do this, to their own personal financial detriment, would often be motivated largely by principles and sentiments of solidarity.

103. See Christian Arnsperger \& Yanis Varoufakis, Toward a Theory of Solidarity, 59 ERKENNTNIS 157, 171 (2003). Generally, we assume herein that genuine solidarity, and certainly the feelings of generosity associated therewith, can in practice be motivational to an extent not typical of a non-solidaristic preference for some form of equality. It might be thought that some persons will find any inequality to be motivationally distasteful, or repugnant. But this sentiment likely attaches more precisely to visible poverty or destitution than to inequality itself. We can safely bypass contested general issues as to whether reasons in themselves can or must be motivating, and whether moral judgments are internally or merely externally related to actual moral motivations. For background, see, e.g., DAVID BRINK, MORAl REALISM AND THE FOUNDATIONS OF ETHICS (1989) (endorsing moral externalism); Connie S. Rosati, Moral Motivation, STANFORD ENCYClOPEDIA OF PHILOSOPHY (rev. ed. July 7,2016$)$ http://plato.stanford.edu/entires/moral-motivation.

104. See Arnsperger \& Varouakis, supra note 103, at 171.

105. See id.

106. See id.

107. See Andreas Eshete, Fraternity, 35 REV. METAPHYSICS 27, 28 (1981).

108. See id. 
"strong feelings of cooperation,"109 as well as "mutual identification."110 Invidious comparisons of current benefactors and beneficiaries under genuine solidarity tends to be reduced. ${ }^{111}$ In sum,

[s]olidarity, in general, is a matter of a group of people being united or at one with regard to something (sympathies, interests, values, etc.), having genuine concern for one another's welfare, respecting others as group members, trusting one another as group members, [and] trusting one another not to intentionally undermine or free ride on the group as a whole. . . ${ }^{112}$

Solidarity, more than the more abstract, if not purely arithmetic, idea of non-solidaristic equality, involves an inherently and directly emotional bonding quality, and thus has a generally greater motivational potential.

The motivational power of genuine solidarity is tested especially clearly, and in both directions, in cases involving chronic disability expenses and the often substantial ${ }^{113}$ costs of medical care in the last (1977).

109. Lawrence Crocker, Equality, Solidarity, and Rawls' Maximin, 6 PHL. \& PuB. AFF. 262, 263

110. Id.

111. See id. For persons who sacrifice substantially as a matter of solidarity with those less well off, such solidaristic motivation cannot possibly be reduced to the idea or emotion of gratitude. For broader discussion of the remarkably interesting and complex nature of gratitude, see TERRANCE MCCONNELL, GRATITUDE (1993).

112. Adam Cureton, Solidarity and Social Moral Rules, 15 ETHICAL TheORY \& MORAL PRAC 691, 696 (2012). These understandings of solidarity seem stronger than the "shared responsibility" view of solidarity endorsed in PAUL Starr, REMEDY AND REACtion: THE PECUllar AMERICAN STRUgGle Over Health CARE REForm 241-42 (rev. ed. 2013). Professor Starr's understanding of solidarity seems compatible with either equality or inequality in health care provision. See id. at 242 . As the great poet and insurance executive Wallace Stevens once pointed out, "universal insurance or insurance for all is not the same thing as ubiquitous insurance or insurance for everything." Wallace Stevens, Insurance and Social Change, in COLLECTED POETRY AND PROSE 792, 792 (Library of America ed., 1997) (1947).

113. There is some evidence that end-of-life or final year of life medical spending, as distinct from spending on chronic conditions over much of a lifetime, may actually be lower than is often imagined. See, e.g., Eric B. French, et al., End-of-Life Medical Spending in Last Twelve Months of Life Is Lower Than Previously Reported, 36 HEALTH AFF. 1211 (2017), http://content. healthaffairs.org/content/36/7/1211.full; Melissa D. Aldridge \& Amy S. Kelley, The Myth Regarding the High Cost of End-of-Life Care, 105 AM. J. PuB. HEALTH 2411, 2414-15 (2015), www.ncbi.nlm.nih.gov/pmc/articles/PMC4638261. ("the cost of caring for individuals in their last year of life accounts for only $13 \%$ of total annual health care spending"). But such costs remain substantial. See, e.g., Michael Bell, Why $5 \%$ of Patients Create $50 \%$ of Health Care Costs, Forbes (July 10, 2013), www.forbes.com/sites/michaelbell/2013/01/10 (" $30 \%$ of all Medicare expenditures are attributed to the $5 \%$ of beneficiaries that die each year, with $1 / 3$ of that cost occurring in the last month of life"). For some complications, see Matthew A. Davis, et al., Identification of Four Unique Spending Patterns Among Older Adults in the Last Year of Life Challenges Standard Assumptions, 35 HEALTH AFF. 1316 (2016), http://content.healthaffairs.org/content/35/7/1316. In general, though, health care costs clearly tend to increase past middle age. See, e.g., Louise Sheiner, Inter-Generational Aspects of Health Care, in THE OXFoRd HandBook OF HeAlth ECONOMICS 280, 280 (Sherry Glied \& Peter C. Smith eds., 2013). 
year or two of life. ${ }^{114}$ One practical complication in this context, though, is that the various costs, and the relative benefits, of alternative forms of medical treatment for persons near the end of their lives may be unclear. ${ }^{115}$ So in some cases, it may correspondingly not be clear which health care principles or policies should be endorsed by those wishing to express solidarity with persons nearing the end of their life.

As many end of life cases illustrate, solidarity should often be to some degree reciprocal, and realistically should be appropriately constrained by considerations of effectiveness and by direct and opportunity cost ${ }^{116}$ concerns. Some basic health care policy preferences may have symbolic, gestural, or expressive meaning. But such preferences should normally take into consideration the importance of limiting the sheer waste of scarce resources. ${ }^{117}$ End of life care, for

114. The recipients of expensive such care may indeed tend to be relatively old, thus triggering discussion of "fair innings" arguments, see supra note 83, but on the other hand, they certainly need not be old or even middle-aged, in which case "fair innings" arguments may cut in the other direction.

115. See, e.g., Anne A. Scitovsky, "The High Cost of Dying": What Do the Data Show?, 83 MILBANK Q. 825 (2005), www.ncbi.lm.nih.gov/pmc/articles/PC2690284 ("[h]ospice care for terminal cancer patients has not yet been proved conclusively to be less costly in all cases than conventional care. Similarly, home care may be more expensive than institutional care in cases where there are no family members available to help in the care of the patient"). Nor is it clear that we should categorize all the expenses of an unsuccessful treatment as misguided or wasteful where there was some appropriate uncertainty of the eventual outcome at the time of the expenditure. See id. See also T. Balboni, et al., Support of Cancer Patients' Spiritual Needs and Associations with Medical Care Costs at the End of Life, 117 CANCER 5838 (December 1, 2011),www.ncbi.nlm.nih.gov/pubmed/21563177 (reporting higher end of life costs when patients perceived that their spiritual concerns were not being appropriately addressed).

116. For background, see, e.g., David R. Henderson, Opportunity Cost, THE ConcisE ENCYCLOPEDIA OF ECONOMICS (2008), www.econlib.org/library/ENC/OpportunityCost.html (roughly, opportunity cost as the forfeited value of the single most valuable foregone alternative use of the resources in question). Too often, cost analysis focuses solely on short-term and occasionally long-term or indirect costs, and not as well on what values are no longer attainable, in or out of the health care area, because of the expenditures in question.

117. See, e.g., Benedict Rumbold, et al., Public Reasoning and Health-Care Priority Setting: The Case of NICE, 27 KENNEDY INST. ETHICS J. 107, $123-24$ (2017), http://muse.jhu.edu/article/652734 (citing Ronald Dworkin, SOVEReign Virtue: The Theory and Practice of EQuality 315 (2000)). Beyond the context of end of life cases, consider the observation of the economist Joseph Stiglitz that "[i]t is not that we spend 17 percent of our GDP on health care that is the problem; it is that we get so little for how much we spend." Joseph E. Stiglitz, Commentary on Amy Finkelstein, in MORAL HAZARD IN HEALTH INSURANCE 66, 69 (2015). Waste often takes the form of ignoring or unduly discounting not just opportunity costs, but the interests of invisible, anonymous, inconspicuous, or merely future victims of an inefficient current policy. For a useful example, see Carroll v. Otis Elevator Co., 896 F.2d 210, 212, 216-17 (7th Cir. 1990) (Easterbrook, J., concurring). For a broad overview, see Charles E. Phelps, Health ECONOMics chs. 1, 16 (5th ed. 2013). For a marketoriented view of the dynamics of the Medicare system, see the satiric, virtue- and vice-sensitive work by David A. Hyman, MEdiCARE MEETS MePhistopheles (2006). For a classic utopian virtue-oriented but non-market focus in considering issues of physician compensation, see EDWARD BELLAMY, LOOKING BACKWARD 2000-1887 103-04 (Cecelia Tichi ed., 1982) (1888). Ultimately, health care economics and the most important value tradeoffs are not entirely reducible to some combination of mere normative preferences, confirmation bias, unexamined intentions, magic, or luck. The tradeoffs are to some extent more inescapably built into the fabric of resource scarcity. 
example, that contributes relatively little on any sensible measure of quality or quantity of life will often be at best poorly justified, even in terms of overall solidarity itself. No moral person, as a general rule, is in all respects outside the scope of both the benefits and burdens of genuine solidarity.

This is not solely a matter of the sense that solidarity itself should not require substantial waste, especially at the expense of other medical patients, in other circumstances, with whom solidarity could be expressed. ${ }^{118}$ Solidarity need not always, at any given time, involve direct reciprocity, or concrete mutuality. ${ }^{119} \mathrm{We}$ can act on the basis of solidarity with future generations with whom we do not overlap. But certainly, in many cases, any impulse toward solidarity on the part of benefactors should evoke some appropriately solidaristic response on the part of beneficiaries, whether the beneficiary can exercise narrowly reciprocal solidarity at any point or not.

Thus for persons nearing the end of life, solidarity should often involve more than the mere feeling of gratitude for expensive care. In many cases, genuine solidarity can be more concretely expressed by, and not simply toward, end of life patients. This form of solidarity can be expressed toward those who subsidize one's end of life care, toward other current sufferers, and toward those persons, perhaps of a later generation, who might benefit in the future by current displays of reasonable self-restraint on the claims that might otherwise be made by end of life patients themselves. Certainly, all persons could conceivably ask for greater solidarity from everyone except themselves. But that motivation, to the extent that it is merely self-seeking, is contrary to the very essence of solidarity itself.

In many instances, the solidaristic sacrifice involved in declining some additional health care spending by end of life patients may be modest in its magnitude. Many such persons would prefer to end their days at home, rather than in some less familiar institutionalized facility. ${ }^{120}$ There may be only limited, if any, personal financial

118. See Rumbold, et al., supra note 117, at 123-24.

119. See supra notes 105-106 and accompanying text. Persons can emotionally feel, and be thereby motivated by, solidarity with both ancestors and future generations, where reciprocity is realistically impossible. Consider the willingness to personally sacrifice substantially today for the sake of preserving environmental and climate quality for future generations with whom, for one reason or another, one identifies.

120. See, e.g., Thomas W. Feeley, The Value of ICU Care at the End of Life, NEJM CATALYST (September 28, 2016), http://catalyst.nejm.org/value-icu-care-end-of-life; Daniela J. Lamas, et al., Opening the Door: The Experience of Chronic Critical Illness in a Long-Term Acute Care Hospital, CRITICAL CARE MEDICINE (2008), www.ccmjournal.org at 361; Joan M. Teno, et al., Change in Endof-Life Care For Medicare Beneficiaries, 309 JAMA 470, 470 (February 6, 2013) ("a majority of people would prefer to die at home if they were terminally ill"). 
sacrifice in exercising the former option. ${ }^{121}$ But any competent person, even in end of life circumstances, may, perhaps through advance directives, appropriately ${ }^{122}$ acknowledge the bonds of solidarity. It would in a sense be degrading to exempt all end of life patients, for whom social memories and broader moral aspirations may be especially important, from any active and in a sense self-sacrificial solidarity toward others.

Some such persons, after all, may wish at a crucially appropriate time to emphasize particular classic virtues, such as fortitude, forbearance, equanimity, self-control, humility, perspective, and generosity of spirit, that reinforce a solidaristic recognition of the tradeoffs associated with one's own presumably especially expensive care. Such virtues have been widely recognized, not just by the historical Stoics, ${ }^{123}$ but by preStoics $^{124}$ and post-Stoics ${ }^{125}$ alike. Thus Seneca classically holds that

[a]n ordinary journey will be incomplete if you come to a stop in the middle of it, or anywhere short of your destination, but life is never incomplete if it is an honorable one. At whatever point you leave, if you leave it in the right way, it is a whole. ${ }^{126}$

121. We assume for this purpose that dying with one's family at home will often, but not always, be less costly for the broader paying public.

122. For a typically inappropriate breach of one of the most intimate and elemental forms of solidarity, consider the common incentivizing of more or less sham divorces for the sake of obtaining long-term care Medicaid funding. See K. Gabriel Heiser, Medicaid Divorce: Is It a Viable Planning Option?, AGINGCARE.COM, www.agingcare.com/articles/medicaid-divorce-planning-option196512.htm (visited July 28, 2017); Rev. Amy Ziettlow, Is Divorce the Best Option for Older Americans? HuFFINGTON POST, available at www.huffingtonpost.com/rev-amy-ziettlow/is-divorce-thebest-option (May 16, 2015) (last visited July 28, 2017). For such cases, appropriate solidarity on the part of the broader public requires some accommodation of the most intimate and elemental forms of solidarity, which in turn are linked to the development and fuller realization, or gradual progress toward perfection, of the human person.

123. See, merely for example, SENECA, LETTERS FROM A STOIC, Letter LXXVII (Robin Campbell trans., 1969) ( $\sim 64)$; SENECA, ON THE SHORTNESS OF LIFE (C.D.N. Costa trans., 1997) (2005 ed.) ( -64$)$; EPICTETUS, THE DisCOURSES book III, ch. 10, at 172 (Robin Hard rev. trans., 1995) ( 140) ("How We Should Bear Illness"); EPICTETUS, THE ENCHIRIDION $\S 2$, at 18 (Thomas W. Higginson trans., 1948) $(\sim 140)$; MARCus AuRELIUS, MeditaTIONS book II, $\S 11$, at 48 (Maxwell Staniforth trans., 1964) $(\sim 167)$.

124. See, e.g., PlATO, THE REPUBLIC book IX, § 5, at 95-96 (Francis MacDonald Cornford trans., 1941) $(\sim 370 \mathrm{BCE})$ (the personage of Herodicus as becoming a plague to himself and others "by lingering out his death. He had a mortal disease, and he spent all of his life at its beck and call, with no hope of a cure and no time for anything but doctoring himself").

125. See, e.g., RALPH Waldo EMERSON, SElf-REllance at 8 (1841), www.emersoncentral.com/selfreliance.htm (referring to "the mutual reverence that is due from man to man"); HenRY DAVID THOREAU, CIVIL DISOBEDIENCE at 6 (1849)http://xroads.virginia.edu/ hyper2/thoreau/civil.html (referring disdainfully to a lack of "cheerful self-reliance" as distinct from a less desirable reliance on "the Mutual Insurance company").

126. SENECA, LETTERS, supra note 123, Letter LXXVII, at 125. Note also Plato's critique of the apparent priorities of Herodicus, supra note 124 , at $95-96$. It is also worth noting that even the apparently controversial Nietzshean injunction to "die at the right time," taken by itself, is open to a 
None of this is to suggest, for patients with especially expensive illnesses or for others, that the reflective pursuit of the overall value of solidarity should always override any other value rightly invoked by any affected party. Solidarity, as developed and understood to this point, can of course motivate and guide optimally only when some reasonable account of other values, virtues, and interests is taken.

An especially important development of the idea of solidarity, and a link to a generally uncontroversial idea of "perfectionism," emphasizes the idea of solidarity extended over time. ${ }^{127}$ Broad solidarity over time could, presumably, contribute to social stability, to sustainability, and to, as we emphasize herein, cultural progress and cultural perfectionism. But solidarity can also sometimes be "merely" expressive, rather than medically effective in terms of substantive outcomes. By invoking the idea of perfectionism, we intend merely to emphasize the moral importance of genuine collective progress and development in health care, broadly and over time. Health care systems should thus be attuned to the possibilities and limitations of what we might thus call the perfectionist solidarity.

It is important to recognize that perfectionist solidarity as we use the term is not intended in the slightest to imply that progress, or overall genuine improvement over time, should be obtained by the coercive or uniform imposition of some officially preferred but contestable single model of what human health, or human flourishing more broadly, should involve. ${ }^{128}$ Nor is perfectionist solidarity at all a matter of focusing on preferences, interests, or enhancement of some presumed elite group. ${ }^{129}$

range of interpretations. See FRIEDRICH NIETZSCHE, THUS SPOKE ZARATHUSTRA 97 (R.J. Hollingdale trans., 1961) (1883).

127. See, classically, Edmund Burke, Reflections on the Revolution in France, in THE PORTABLE EDMUND BURKE 416, 458 (Isaac Kramnick ed., 1999) (1790) (depicting society as a multi-generational ongoing partnership encompassing, importantly for our purposes, "all perfection").

128. As is recognized even by critics of perfectionism. See STEVEn LeCCE, AGAINST PERFECTIONISM: DEFENDING LIBERAL NEUTRALITY 117 (2008).

Professor Matthew Kramer in this context attempts to distinguish between a governmentinitiated perfectionism that seeks more or less directly to promote upgraded lives of the citizenry, and a similarly government-initiated perfectionism that pursues a similar end more indirectly, through operating first on the quality or stature of the society itself, as distinct from its members. Professor Kramer refers to the first form as "edificatory" perfectionism, and to the second form as "aspirational" perfectionism, with the first form being much more commonly advocated than the latter. See MATTHEW H. KRAMER, LIBERALISM WITH EXCELLENCE 36 (2017).

Assuming that these two forms of perfectionism can be distinguished in practice, it would seem that many perfectionists would naturally be attracted to some sort of mixture of Professor Kramer's above direct and indirect approaches toward perfectionism. To the extent that a choice must be made between the two, the argument for perfectionist solidarity herein would, in focusing on basic policy justifications for health law and policy, seem more indirect than direct. See Kramer, id. at 33-39.

129. See, e.g., STEVEN WALl, LiBERALISM, PERFECTIONISM AND RESTRAINT 19 (2006 ed.) (1998) (distinguishing between "universal perfectionism" and "parochial perfectionism"); THOMAS HURKA, 
The idea of perfectionist solidarity does not negate the foundational element of broad social solidarity itself. ${ }^{130}$

One form of perfectionist solidarity was historically expressed as "the settled disposition on each man's part to make the most and best of humanity in his own person and in the persons of others."131 This conception of perfectionist solidarity thus emphasizes broad, if not universal, development, self-realization, and flourishing. ${ }^{132}$ As inseparable as health care law and policy is from broader measures of well-being, it is hardly surprising that good health ${ }^{133}$ and at least some realistic access to basic health care ${ }^{134}$ are typically crucial to human development, flourishing, and perfection. Flourishing and gradual cultural perfection over time through health care will thus require genuine collective economic, scientific, and technical progress.

Solidaristic progress can unfortunately be slowed or reversed by unwise policy choices. It is in the long run enabled and promoted by what we might call broad genuine underlying economic progress and development, or genuine growth. ${ }^{135}$ There can also of course be social solidarity without any meaningful dimension of progress or social perfection. There can be a solidarity of slow genuine growth, stagnation, ignorance, and delusion. But there is also a solidarity of collective achievement, of enhanced understanding, and of overcoming barriers to the promotion of health, taking some form of what we have

PERFECTIONISM 147 (1993) ("[t]he best political act, institution, or government is that which most promotes the perfection of all humans").

130. See the sources cited supra note 129 .

131. Thomas Hill Green, Prolegomena to Ethics $§ 244$, at 262 (Nabu reprint ed.) (3d ed. 1890).

132. See David O. Brink, Perfectionism and the COMmon GoOd: Themes in the PHILOSOPHY OF T.H. GREEN 53 (2003).

133. See Michael J. Sandel, The Case Against Perfection 48 (2007) ("[g]ood health, like good character, is a constitutive element of human flourishing"). It is worth noting that Professor Sandel's argument against a form of 'perfection' really opposes something like supra-human or nonhuman perfection, as distinct from our concern herein for the progressive cultural development of humanity.

134. See Brink, supra note 132, at 48 ("[b]asic healthcare is essential not just to making possible a decent lifespan but also to the proper development of young minds and bodies").

135. The fact that it is apparently difficult to meaningfully address productivity growth issues by consensual means does not mean that this problem is less than crucial. For discussion, see ROBERT J. Gordon, The Rise ANd Fall of AMERICAN Growth $641-52$ (2016); Neil Irwin, Why Is Productivity Growth So Weak? Three Theories, N.Y. TIMES (April 26, 2016), www.nytimes.com/2016/04/29/upshot/why-is-productivity-growth-so-weak-three-theories.html; 23 Economic Experts Weigh In: Why Is Productivity Growth So Low?, Focus Economics (April 20, 2017), www.focus-economics.com/blog/why-is-productivity-growth-so-low.; Jonathan Rockwell, No Recovery: An Analysis of Long-Term U.S. Productivity Decline, Gallup.com (2016), http://news.gallup.com/reports/198776/no-recovery-analysis-long-term-productivity-decline.aspx. Of course, as many cases of disability and other illnesses suggest, collective health, along with health law and policy, can affect productivity rates and in turn reciprocally be affected by those rates. 
herein called perfectionist solidarity.

To more clearly see the value of distinctively perfectionist versions of solidarity, it is best to consider how particular areas of health care treatment have evolved over the preceding centuries. Consider, merely for example, the realm of prescription drug therapies for various psychological ailments. We often sense, even today, the crude fumbling inadequacies of even our best current efforts in this area, where the inadequacies are largely traceable to our insufficiently developed understanding of the relevant sciences. ${ }^{136}$ And at the same time, we recognize incontestable progress in those respects over our prior even more pervasive ignorance. ${ }^{137}$ MRIs are an upgrade over phrenology, or a focus on the four bodily humors, or the application of leeches, or pregerm theory in general. Blood-typing involved recognizable progress. Genuine solidaristic progress in health care, as in the transition from saws to arthroscopes, is ultimately linked to human dignity.

The costs to present generations of making provision for meaningful progress over time need not be onerous. ${ }^{138}$ Crucially, insofar as solidarity obtains between generations, sacrifice on behalf of future generations is actually reduced to the extent that earlier generations freely and genuinely identify with later cohorts' achievements. There is appropriate pride to be taken being a "founding generation," or in making causally necessary savings, investment, or other contributions to an inspiring multi-generational project. ${ }^{139}$ As well, generational interests can reasonably be seen as to some degree blurred. Collectively, investing at age 30 in basic science, in hopes of disease prevention or cure, may pay off perhaps 20-40 years later, in time even for one's own personal medical benefit. ${ }^{140}$ In several respects, then, the conflicts between reasonably enlightened self-interest and relatively

136. See, e.g., Sonya Vatomsky, When Medication Side Effects Make You Rethink What It Means to Have a Good Life, THE CUT (July 28, 2017), https://www.thecut.com/article/antidepressant-sideeffects-quality-of-life.html.. More generally, see What Is Precision Medicine, US NATIONAL LIBRARY OF MEDICINE (July 25, 2017), https://ghr.nlm.nih.gov/primer/precisionmedicine (discussing the NIH's Precision Medicine Initiative). See also PRECISION HEALTH INITIATIVE, INDIANA UNIVERSITY, https://precisonhealth.iu.edu/ (visited July 28, 2017)

137. Compare, for example, the limited therapeutic benefits of historically practiced patient bloodletting, see Elena Conis, When Bleeding Was a Treatment, L.A. TIMES (June 26, 2006), http://articles.latimes.com/2006/jun/26/health/he-esoterica26, with the vast potential for medical exploitation of a fuller understanding of the human genome. See, e.g., A QuARTER CENTURY AFTER the Human Genome ProJect's Launch: Lessons Beyond the Base Pairs, National Human GENOME RESEARCH INSTITUTE (December, 2015), wWw.genome.gov/27562713/nhgri-celebrateslaunch.

138. See, e.g., the exceptionally thoughtful account in Tim Mulgan, Future People: A Moderate CONSEQuentialist account of Our Obligations to Future Generations 218-19 (2006).

139. See id. at 219

140. See id. 
strong forms of perfectionist solidarity in health care law and policy need not be discouragingly severe.

\section{CONCLUSION}

We began our inquiry by considering the difficult interest balancing involved in access to not yet fully approved prescription drugs by terminally ill patients, ${ }^{141}$ and the conflicting interests at stake in attempts to distribute the costs of Medicaid eligibility for the middle class elderly in particular. ${ }^{142}$ These and related conflicts in other areas of health care law and policy are occasionally understated in popular advocacy rhetoric, but understatement does not abolish the underlying conflicts.

The first constructive step toward the best available underlying theory of health care is to try to build some attention to the inevitable value conflicts into even apparently technical inquires, including, for example, whether a proposed treatment is "medically necessary." 143 Ultimately, our most defensible responses to undeniable value conflicts and tradeoffs must address such conflicts at the most basic level. We have seen above, though, that approaches involving the general idea of equality quickly divide into conflicting camps. ${ }^{144}$ Much more importantly, however, the various forms of equality, separate and apart from genuine solidarity, community, the desire for collective progress, and similar sentiments and relationships, turn out to be rather abstract, and in themselves not especially useful motivators of any real and sustained inclination to freely and reasonably sacrifice for the sake of others. ${ }^{145}$

What, then, can we summarily conclude about our two initial exemplary cases? ${ }^{146}$ In both cases, pursuing the various ways in which the most directly affected persons either are or are not being treated as equals of other classes of persons leads us into multiple indeterminacies. But far more importantly, chasing the various forms of equality leads us into abstraction conceptions with little realistic power to sufficiently

141. See supra notes 7-18 and accompanying text.

142. See supra notes $19-38$ and accompanying text

143. See, e.g., Ariana M. v. Humana Health Plan, 854 F.3d 753, 755 (5th Cir.), reh'g en banc granted on other issues, 2017 WL 3029158 (July 10, 2017) (mem). The health care plan in Ariana M. specified that in order to qualify as "medically necessary," a proposed treatment must, among other requirements, be "[n]ot more costly than an alternative service or sequence of services at least as likely to produce equivalent therapeutic or diagnostic results as to the diagnosis or treatment of the patient's sickness or bodily injury." Id. at 755. For general background see Eric Posner \& Matthew D. Adler, Re-Thinking Cost-Benefit Analysis, 109 Y ALE L.J. 165 (1999).

144. See supra Section II.

145. See supra Section III.

146. See supra Section I 
motivate either the affected persons or those actors who are in a position to affect the relevant policies. ${ }^{147}$ Perfectionist solidarity, on the other hand, can more clearly transcend the abstractness of the contending approaches to the idea of equality, and more sustainably motivate a viable and otherwise defensible fundamental approach to health care law and policy.

147. See infra Section II. As well, recall our conclusion that the value of individual freedom is in most contexts appropriately assigned a secondary, though broadly relevant, value in typical health care cost allocation contexts. See supra note 80 . 
